\title{
Teaching NeuroImages: Hirayama Disease With Symmetric Atrophy of Bilateral Distal Upper Extremities
}

Ye Liu, MD, PhD, * Yue Zhang, MD, * and Qiang Dong, MD

Neurology ${ }^{\circledR}$ 2021;96:e2899-e2900. doi:10.1212/WNL.0000000000011380

Figure Photography of the Patient's Hands and Neck MRI

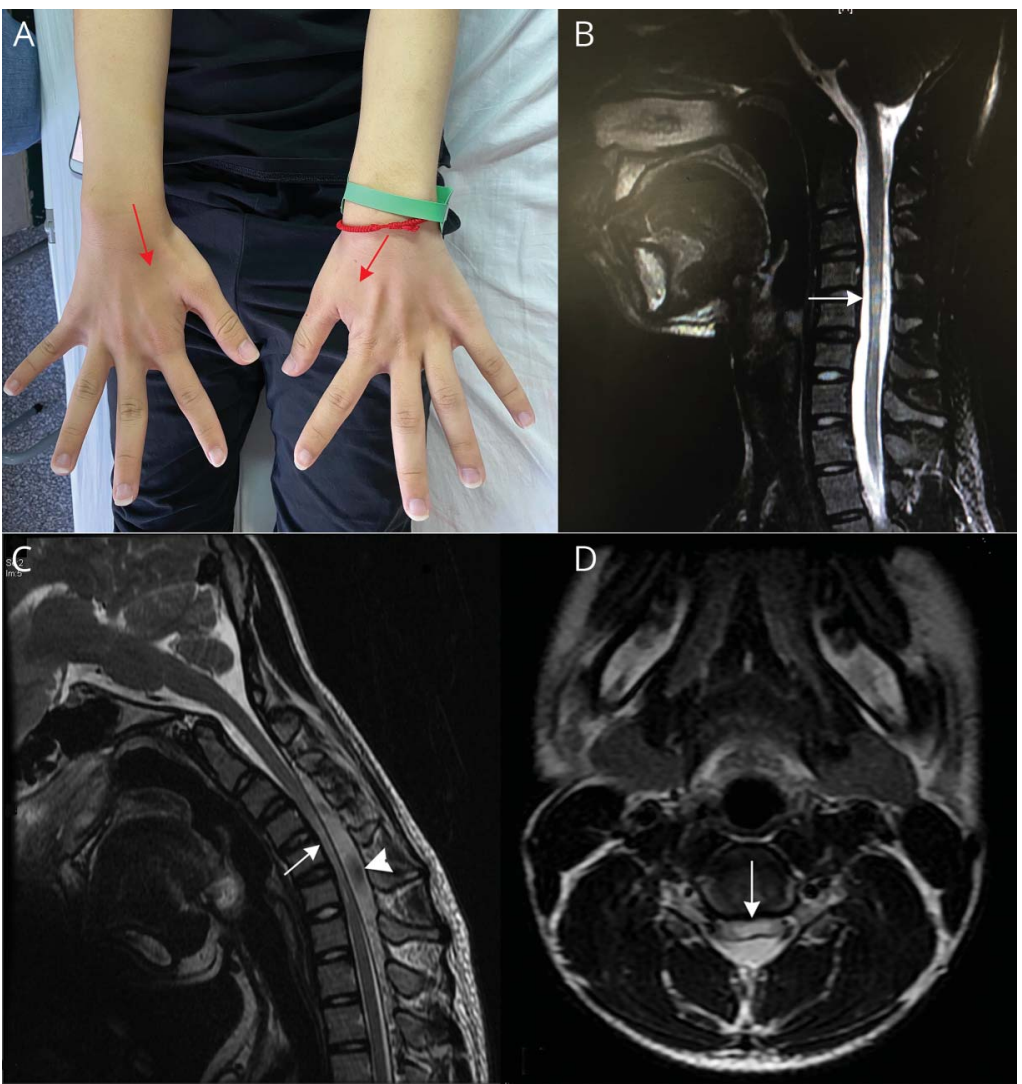

(A) Wasting of bilateral dorsal interossei muscle. (B) Neutral sagittal T2-weighted MRI shows cord thinning and hyperintense signal at C5 to C7 levels. Neck-flexion sagittal (C) and axial (D) T2-weighted MRI show crescent-shaped enlarged posterior epidural space below C3 with flow void causing bilaterally symmetric flattening of the lower cervical cord.

A 15-year-old boy presented with progressive left to bilateral hand weakness and cold paresis over 1 year. Examination revealed atrophy of upper limb musculature, especially bilateral dorsal interossei muscle. Neutral MRI showed cord thinning and intramedullary hyperintensity at C5-C7 levels. Neck flexion MRI demonstrated bilaterally symmetric spinal cord compression due to dural sac anterior shifting (figure), suggestive of Hirayama disease (HD). HD mimics amyotrophic lateral

\section{Correspondence}

Dr. Dong

dong_qiang@fudan.edu.cn
MORE ONLINE

$\rightarrow$ Teaching slides

lww.com/WNL/B302

*These authors contributed equally to this work.

From the Department of Neurology, Fudan University Affiliated Huashan Hospital, Shanghai, China.

Go to Neurology.org/N for full disclosures. Funding information and disclosures deemed relevant by the authors, if any, are provided at the end of the article.

The Article Processing Charge was funded by the authors.

This is an open access article distributed under the terms of the Creative Commons Attribution-NonCommercial-NoDerivatives License 4.0 (CC BY-NC-ND), which permits downloading and sharing the work provided it is properly cited. The work cannot be changed in any way or used commercially without permission from the journal. 
sclerosis-like symptoms and features an expansion of the dural sac on neck flexion MRI. ${ }^{1}$ The majority of $\mathrm{HD}$ is unilateral or asymmetric but bilateral symmetric involvement is reported in $10 \%$ of patients and indicates more severe affliction. ${ }^{2}$

\section{Study Funding}

No targeted funding reported.

\section{Disclosure}

The authors report no disclosures relevant to the manuscript. Go to Neurology.org/N for full disclosures.

\section{Appendix Authors}

\begin{tabular}{|c|c|c|}
\hline Name & Location & Contributions \\
\hline $\begin{array}{l}\text { Ye Liu, } \\
\text { MD, } \\
\text { PhD }\end{array}$ & $\begin{array}{l}\text { Fudan University affiliated } \\
\text { Huashan Hospital, } \\
\text { Shanghai, China }\end{array}$ & $\begin{array}{l}\text { Drafting/revision of the } \\
\text { manuscript for content, } \\
\text { including medical writing for } \\
\text { content; major role in the } \\
\text { acquisition of data }\end{array}$ \\
\hline
\end{tabular}

Appendix (continued)

\begin{tabular}{lll}
\hline Name & Location & Contributions \\
\hline $\begin{array}{l}\text { Yue } \\
\begin{array}{l}\text { Zhang, } \\
\text { MD }\end{array}\end{array}$ & $\begin{array}{l}\text { Fudan University affiliated } \\
\text { Huashan Hospital, } \\
\text { Shanghai, China }\end{array}$ & $\begin{array}{l}\text { Drafting/revision of the } \\
\text { manuscript for content, } \\
\text { including medical writing for } \\
\text { content; study concept or design }\end{array}$ \\
\hline $\begin{array}{l}\text { Qiang } \\
\text { Dong, } \\
\text { MD }\end{array}$ & $\begin{array}{l}\text { Fudan University affiliated } \\
\text { Huashan Hospital, } \\
\text { Shanghai, China }\end{array}$ & $\begin{array}{l}\text { Major role in the acquisition of } \\
\text { data, study concept or design }\end{array}$ \\
\hline
\end{tabular}

\section{References}

1. Huang YL, Chen CJ. Hirayama disease. Neuroimaging Clin N Am 2011;21:939-950.

2. Pradhan S. Bilaterally symmetric form of Hirayama disease. Neurology 2009;72: 2083-2089. 


\section{Neurology}

\section{Teaching NeuroImages: Hirayama Disease With Symmetric Atrophy of Bilateral Distal Upper Extremities}

Ye Liu, Yue Zhang and Qiang Dong

Neurology 2021;96;e2899-e2900 Published Online before print January 4, 2021

DOI 10.1212/WNL.0000000000011380

\section{This information is current as of January 4, 2021}

Updated Information \& Services

References

Subspecialty Collections

Permissions \& Licensing

Reprints including high resolution figures, can be found at: http://n.neurology.org/content/96/23/e2899.full

This article cites 2 articles, 1 of which you can access for free at: http://n.neurology.org/content/96/23/e2899.full\#ref-list-1

This article, along with others on similar topics, appears in the following collection(s):

All Clinical Neurology

http://n.neurology.org/cgi/collection/all_clinical_neurology All Spinal Cord

http://n.neurology.org/cgi/collection/all_spinal_cord MRI

http://n.neurology.org/cgi/collection/mri

Information about reproducing this article in parts (figures,tables) or in its entirety can be found online at:

http://www.neurology.org/about/about_the_journal\#permissions

Information about ordering reprints can be found online:

http://n.neurology.org/subscribers/advertise

Neurology ${ }^{\circledR}$ is the official journal of the American Academy of Neurology. Published continuously since 1951, it is now a weekly with 48 issues per year. Copyright Copyright ( 2021 The Author(s). Published by Wolters Kluwer Health, Inc. on behalf of the American Academy of Neurology.. All rights reserved. Print ISSN: 0028-3878. Online ISSN: 1526-632X.

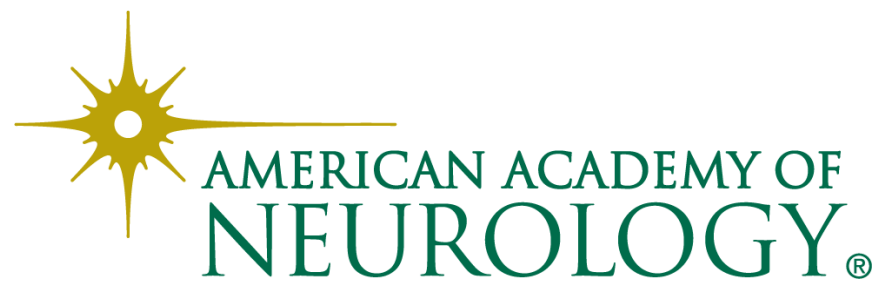

